\title{
Livelihood Enhancement of Vulnerable Farm Families through Integrated Farming Systems of Southern Districts of Karnataka
}

\author{
Nagaraju .Y $Y^{1}$ Raghavendra . $N^{2}$, Basavaraj . $B^{3}$ \\ ${ }^{1} \mathrm{Ph} . D$. Scholar, Center for Study of Social Exclusion and Inclusive Policy, Bharathidasan University, Tiruchirappalli. Tamil Nadu, India \\ ${ }^{2}$ Research Fellow Department of Economics, Kuvempu University, Shankarghatta, Shimoga, Karnataka \\ ${ }^{3} \mathrm{Ph} . \mathrm{D}$. Scholar, Department of Economics \& Commerce, CMR University Bangalore, Karnataka
}

\begin{abstract}
Study focus of to analyze the economics of livelihood improvement for resource poor rural community in Shimoga, Chitradurga Bangalore rural and Chickballapur districts of Karnataka state. During the year 2010-2012 The study was purposive selected randomly 650 respondents comprising of resource poor farmers across the study area. It is a unique approach aims at minimizing the risk and increase in net returns of the farmers the primary data obtained through personal interview method using pretested schedule. The integrated farming with paddy, groundnut, maize, ragi and sericulture with integration of other enterprises such as dairy, sheep and poultry resulted in higher net income; employment opportunities Crop production and animal components are major components of IFS in contribution to the increase in the net income of farmers. The average income has increased to Rs. 77851 from Rs. 37015 in a span of two years in project implemented area. The Project has created awareness among beneficiaries on improved practices of agriculture, soil health, bio-resource recycling, and integration of various components, processing, value addition and marketing. It has created employment generation throughout the year. The intervention of the project has prevented rural migration of farmers.
\end{abstract}

Keywords: Integrated farming system, Farming Community and IFS beneficiaries, Self-Help Groups, and Scheduled Caste farm families

\section{Preamble}

Integrated farming system is integration of two or more appropriate combination of enterprises like crop, dairy, piggery, fishery, poultry, bee keeping etc., for each farm according to the availability of resources to sustain and satisfy the necessities of the farmer Over the last five decades, in the name of agriculture and rural development, extension has been pushed around and designed to "helping people to help themselves" by relating technologies to the needs and opportunities of the farmers. It has been put to serve some production oriented programmes, area development initiatives, target group based service schemes and largely, as a technology delivery mechanism with the goal of attaining self-sufficiency in food production.

The agricultural production systems are largely dependent on rainfall, vagarious climate, and biophysical environment including market dynamics. Continuously, threatened livelihood systems lead to low income generation, insecurity in food production, and compels to live in below poverty line (BPL). Switching over to alternate production systems, or adoption of modern production practices are far beyond the scope of SC farmers due to their poor resource base and economic conditions.

The basic approach of agricultural extension focuses on extension reach to small, marginal / rural women/rural youths. It also includes strengthening and up-scaling of ongoing extension reforms, provision of quality manpower and promotion of commodity based farmers organizations and thrust on market-led extension.
Farming system brings the crops and livestock into an interactive relationship. It will generate positive effects on outcomes such as profitability, overall productivity and conservation of non-renewable resources. The "System" includes the environment, soil characteristics, landscape positions, genetics and ecology of plant \& animals. It involves management practices, goals \& lifestyles of humans, social constraints, economic opportunities, marketing strategies and externalities including energy supplies and costs and impacts of farm policies.

IFS approach as a bio-physical and socio-economic capsule has immense potential to address instability of income, food and nutritional security, unemployment, vulnerability and poverty of farmers as well as landless laborers. Yield maximization of all component enterprises to provide steady and stable income rejuvenation of system's productivity and to achieve agro - ecological equilibrium.

\section{Aims of IFS}

Increased productivity, profitability, sustainability, balanced food, non polluted environment, recycling of resources, income round the year, solving fuel and fodder crises, energy crises, , efficient use of input - output , enhanced opportunities in agriculture, increased employment generation and income and living standard of the farmers.

In this direction, the Directorate of Extension, University of Agricultural Sciences, Bangalore is implementing a project entitled "Development of resource poor farmers in 17 districts of southern Karnataka through integrated farming system (IFS) approach" funded by Karnataka State 


\section{International Journal of Science and Research (IJSR) \\ ISSN (Online): 2319-7064}

Index Copernicus Value (2015): 78.96 | Impact Factor (2015): 6.391

Department of Agriculture under Special Component Programme, Government of Karnataka. This project is being implemented in 17 districts of southern Karnataka during 2010-12 covering 56 cluster villages comprising of 650 farm families with the following objectives

- To diversify the production systems for enhanced output and income

- To generate employment opportunity through diversified production system

The IFS farmers Self-Help Groups were formed in the selected cluster villages and registered. The on-campus and off-campus trainings were organised on various components of IFS. The necessary inputs like HYV seeds, saplings/grafts, animals (sheep, cow, poultry birds) etc. were distributed to the farmers. The team of specialists will provide the necessary technical guidance. The monitoring and supervision is inbuilt mechanism of the project for effective implementation.

\section{Methodology}

The benchmark survey conducted in the seventeen districts of southern Karnataka from selected Scheduled Caste farmers involved in different farming activities combined with allied enterprise are being adopted by the farmers four districts were randomly selected Shimoga, Chitradurga Bangalore rural and Chickballapur. Total of 650 farmers involved in integrated farming system viz. crop production, horticulture, dairy, poultry, sheep and goat rearing, piggery, bee keeping and kitchen gardening were taken for the study from each districts.

\section{The research instrument}

In order to collect relevant information for the study, a structural interview schedule was prepared carefully keeping the objectives of the study in mind. The questions and statement contained in the schedule were simple, direct and easily understandable by the respondent.

\section{Data collection and analysis}

Data were collected during March- April, 2010 through face to face interview by using structured interview schedule. Tabular analysis was used to interpret the collected data properly. Collected data were compiled, coded, tabulated and analyzed according to the objectives of the study.

\section{Results and Discussion}

\section{Crop production}

These operations include selection and treatment of seed, protection of the seed or plant material, land preparation, application of manures and fertilizers, sowing or planting, nursery raising, irrigation, intercultural and weeding, earthing up, pinching or thinning training and pruning top dressing, plant protection, harvesting, transport and post harvest operations such as threshing, winnowing, sieving, cleaning, drying, grading, packaging and storage They also do marketing or disposal of the farm produce. For household use they take care in hulling, flouring, pounding etc. In Shimoga and Chitradurga districts for crop production farmers involvement is (14.22 percent) and (14.41 percent) .In Shimoga and Chitradurga districts from crop production farmers were getting income of Rs. 17794 and Rs. 15000.60 respectively before the implementation of the IFS project. Whereas after the implementation of the project with regular guidance and support in Shimoga and Chitradurga districts from crop production farmers got the income of Rs. 36000 and Rs. 30901 respectively (Tables 1 and 2).

In the case of Bangalore Rural and Chickballapur districts farmer's involvement is 13.23 per cent and 13.11 per cent respectively. For crop production, in Bangalore Rural and Chickballapur districts farmers were getting income of Rs. 18196 and Rs. 19356 before the implementation of project. (Tables 3 and 4). After the implementation of the project with regular guidance and support of agricultural scientists in Bangalore rural and Chickballapur districts from crop production farmers got the income of Rs. 37483 and Rs. 39873 respectively.

Table 1: Income and employment generation from Integrated farming system before and after implementation of the project in Shimoga district

\begin{tabular}{|c|c|c|c|c|c|}
\hline $\begin{array}{l}\text { Sl. } \\
\text { No. }\end{array}$ & Particulars & $\begin{array}{l}\text { No. of farmers involved in } \\
\text { agriculture and allied activities }\end{array}$ & $\begin{array}{l}\% \text { of } \\
\text { total }\end{array}$ & $\begin{array}{l}\text { Pre project income from agriculture } \\
\text { and allied activities per annum (Rs.) }\end{array}$ & $\begin{array}{l}\text { Post project income from agriculture } \\
\text { and allied activities per annum (Rs.) }\end{array}$ \\
\hline 1 & Crop production & 33 & 14.22 & 17794 & 36000 \\
\hline \begin{tabular}{|l|}
2 \\
\end{tabular} & Horticulture & 30 & 12.93 & 2275 & 5362 \\
\hline 3 & Dairy & 28 & 12.07 & 2536 & 5236 \\
\hline 4 & Poultry & 25 & 10.78 & 1276 & 2360 \\
\hline 5 & Sheep & 26 & 11.21 & 2487 & 5062 \\
\hline 6 & Goat & 24 & 10.34 & 2635 & 3712 \\
\hline 7 & Piggery & 20 & 8.62 & 0.00 & 17920 \\
\hline 8 & Bee keeping & 22 & 9.48 & 813 & 1200 \\
\hline & Total & 232 & 100 & 34201 & 76852 \\
\hline
\end{tabular}

Source : Survey data (2010-12) 


\section{International Journal of Science and Research (IJSR) \\ ISSN (Online): 2319-7064 \\ Index Copernicus Value (2015): 78.96 | Impact Factor (2015): 6.391}

Table 2: Income and employment generation from Integrated farming system before and after implementation of the project in Chitradurga district

\begin{tabular}{|c|c|c|c|c|c|}
\hline $\begin{array}{l}\text { Sl. } \\
\text { No. }\end{array}$ & Particulars & $\begin{array}{l}\text { No. of farmers involved in } \\
\text { agriculture and allied } \\
\text { activities }\end{array}$ & $\begin{array}{l}\% \text { of } \\
\text { total }\end{array}$ & $\begin{array}{l}\text { Pre project income from agriculture } \\
\text { and allied activities per annum (Rs.) }\end{array}$ & $\begin{array}{l}\text { Post project income from agriculture } \\
\text { and allied activities per annum (Rs.) }\end{array}$ \\
\hline 1 & Crop production & 32 & 14.41 & 15000 & 30901 \\
\hline 2 & Horticulture & 30 & 13.51 & 1802 & 3712 \\
\hline 3 & Dairy & 26 & 11.71 & 5326 & 10971 \\
\hline 4 & Poultry & 26 & 11.71 & 836 & 1722 \\
\hline 5 & Sheep & 31 & 13.96 & 2492 & 5133 \\
\hline 6 & Goat & 30 & 13.51 & 2915 & 6004 \\
\hline 7 & Piggery & 25 & 11.26 & 1500 & 3090 \\
\hline 8 & Bee keeping & 22 & 9.91 & 500 & 1030 \\
\hline & TOTAL & 222 & 100 & 30371 & 62565 \\
\hline
\end{tabular}

Source : Survey data (2010-12)

Table 3: Income and employment generation from Integrated farming system before and after implementation of the project in Bangalore Rural district

\begin{tabular}{|c|c|c|c|c|c|}
\hline $\begin{array}{c}\text { Sl. } \\
\text { No. }\end{array}$ & Particulars & $\begin{array}{c}\text { No. of farmers involved in } \\
\text { agriculture and allied activities }\end{array}$ & $\begin{array}{c}\% \text { of } \\
\text { total }\end{array}$ & $\begin{array}{c}\text { Pre project income from agriculture } \\
\text { and allied activities per annum (Rs.) }\end{array}$ & $\begin{array}{c}\text { Post project income from agriculture } \\
\text { and allied activities per annum (Rs.) }\end{array}$ \\
\hline 1 & Crop production & 25 & 13 & 18196 & 37483 \\
\hline 2 & Horticulture & 23 & 12 & 8945 & 18426 \\
\hline 3 & Dairy & 25 & 14 & 4658 & 9595 \\
\hline 4 & Poultry & 24 & 12 & 585 & 1205 \\
\hline 5 & Sheep rearing & 25 & 14 & 3280 & 6756 \\
\hline 6 & Goat rearing & 25 & 13 & 1823 & 3755 \\
\hline 7 & Piggery & 22 & 11 & 1206 & 2484.36 \\
\hline 8 & Bee keeping & 20 & $\mathbf{1 0 0}$ & $\mathbf{3 9 1 6 8}$ & 978.5 \\
\hline & TOTAL & $\mathbf{1 8 9}$ & & $\mathbf{8 0 6 8 6}$ \\
\hline
\end{tabular}

Source : Survey data (2010-12)

Table 4: Income and employment generation from Integrated farming system before and after implementation of the project in Chickballapur district

\begin{tabular}{|c|l|c|c|c|c|}
\hline $\begin{array}{c}\text { S1. } \\
\text { No. }\end{array}$ & Particulars & $\begin{array}{c}\text { No. of farmers involved in } \\
\text { agriculture and allied activities }\end{array}$ & $\begin{array}{c}\text { Percentage of } \\
\text { total activities }\end{array}$ & $\begin{array}{c}\text { Income from agriculture and } \\
\text { allied activities per annum } \\
\text { (Rs.) }\end{array}$ & $\begin{array}{c}\text { Income from agriculture and } \\
\text { allied activities per annum (Rs.) }\end{array}$ \\
\hline & & & & Before Implementation & After Implementation \\
\hline 1 & Crop production & 24 & 13.11 & 19356 & 39873.36 \\
\hline 2 & Horticulture & 24 & 13.11 & 12000 & 24720 \\
\hline 3 & Dairy & 23 & 12.57 & 6000 & 12360 \\
\hline 4 & Poultry & 24 & 13.11 & 500 & 630 \\
\hline 5 & Sheep rearing & 24 & 13.11 & 3300 & 3914 \\
\hline 6 & Goat rearing & 22 & 12.02 & 1900 & 1648 \\
\hline 7 & Piggery & 22 & 12.02 & 800 & 957.9 \\
\hline 8 & Bee keeping & 20 & 10.93 & 465 & $\mathbf{4 4 3 2 1}$ \\
\hline \multicolumn{2}{|c|}{ TOTAL } & $\mathbf{1 8 3}$ & $\mathbf{1 0 0}$ & & $\mathbf{9 1 3 0 1}$ \\
\hline
\end{tabular}

Source : Survey data (2010-12)

\section{Horticulture}

Farmers involved in seed collection and extraction, raising seedlings or cuttings, land preparation and sowing/ transplanting, manorial application, providing staking tying, shade and mulching, weeding, pollination, bagging and thinning of flowers and fruits, plant protection, harvesting, collection and transport, clearing and grading, marketing, processing

In Shimoga and Chitradurga districts, proportion of farmer involved in horticulture was found to be 12.93 and 13.51 per cent respectively and were getting income of Rs. 2275 and Rs. 1802 respectively before the implementation of project. For horticulture, in Shimoga and Chitradurga districts after the implementation of project farmers got the income of Rs.5362 and Rs. 3712 per annum was (Tables 1 and 2).
Where as in the case of Bangalore Rural and Chickballapur districts, proportion of farmer involved in horticulture was found to be 12.17 and 13.11 per cent respectively and were getting income of Rs. 8945 and Rs. 12000 respectively. For horticulture, in Bangalore Rural and Chickballapur districts after the implementation of the project farmers got income of Rs. 18426.70 and Rs. 24720 respectively (Tables 3 and 4).

\section{Dairying}

Dairying is another agro-based industry which makes the family income better besides providing milk, curds, butter milk, butter, ghee, and other products thus helping the family members to maintain good health. However, it requires utmost care every hour. Most of these works are carried out by women. Women contribute more labour in activities such as collecting and processing of feed, feeding,

\section{Volume 6 Issue 1, January 2017




\section{International Journal of Science and Research (IJSR) \\ ISSN (Online): 2319-7064}

Index Copernicus Value (2015): 78.96 | Impact Factor (2015): 6.391

milking, marketing of milk, cleaning of sheds and fetching of water for animals.

In Shimoga and Chitradurga districts, proportion of farmer involved in dairying was found to be 12.07 and 11.71 per cent respectively and before the implementation of the project they were getting income of Rs. 2536.00 and Rs. 5326 respectively. For Dairying, in Shimoga and Chitradurga districts after the implementation of project farmers got the income of Rs.5236 and Rs. 10971 respectively (Tables 1 and 2).

Where as in the case of Bangalore Rural and Chickballapur districts, proportion of farmer involved in dairying was found to be 13.23 and 12.57 per cent respectively and were getting income of Rs. 4658 and Rs. 6000 respectively before the implementation of the project. For dairying, in Bangalore Rural and Chickballapur districts after the implementation of project farmers income was raised to Rs. 9595.48 and Rs. 12360 (Tables 3 and 4).

\section{Sheep and goat rearing}

Farmer contribute more labour in activities such as collecting and processing of feed, feeding, cleaning of sheds and fetching of water for animals (Fig 9).

In Shimoga district and Chitradurga district, the proportion of farmer involved in sheep, goat rearing was found to be $11.21,10.34$ and 13.96 , and 13.51 respectively and getting income of Rs. 2487, Rs. 2635 and Rs. 2492.00, Rs. 2915 respectively before the implementation of the project. After the implementation in Shimoga and Chitradurga districts, for sheep and goat rearing with all guidance from the scientists, farmers got the income Rs. 5062, Rs. 3712 and 5133.52 Rs. 6004.9 respectively (Tables 1 and 2).

Where as in the case of Bangalore Rural and Chickballapur districts, proportion of farmer involved in sheep and goat rearing was found to be 13.23 per cent and 13.11 per cent, 12.02 per cent respectively and were getting income of Rs. 3280, Rs. 1823 and Rs. 3300, Rs. 1900 respectively. In Bangalore Rural and Chickballapur districts after the implementation of the project for sheep and goat rearing farmer got income Rs. 6756.80, 3755.38 and Rs. 6798, Rs.3914 respectively (Tables 3 and 4).

\section{Poultry}

Poultry keeping in most of the developing countries is the responsibility of women. In the study area, women look after the birds and the earnings from the sale of eggs and chickens are often their only source of cash income

In Shimoga and Chitradurga districts, proportion of farmer involved in poultry was found to be 10.78 and 11.71 per cent respectively and were getting income of Rs. 1276 and Rs. 836 respectively. For poultry, in Shimoga and Chitradurga districts, after the implementation of the project in their place the income level was increased to Rs. 2360 and Rs. 1722.16 respectively (Tables 1 and 2 ).

Where as in the case of Bangalore Rural and Chickballapur districts, proportion of farmer involved in poultry was found to be 12.70 and 13.11 per cent respectively and were getting income of Rs. 585 and Rs. 500 before the implementation of the project respectively. For poultry, in Bangalore Rural and Chickballapur districts after the implementation of the project with all the support, training and guidance the income level was increased to Rs. 1205.10 and Rs. 1030.00 respectively (Tables 3 and 4).

\section{Piggery}

With regard to pig rearing most of the times improved breeds such as Yorkshires are rearing in most of the districts in Karnataka. Women contribute more labour in activities such as collecting and processing of feed, feeding, cleaning of sheds and fetching of water for animals .In Shimoga district farmers were not rearing pigs but in Chitradurga district, the proportion of farmer involved in piggery was found to be 11.26 and were getting income of Rs. 1500 before the implementation of the project. For piggery, in Shimoga and Chitradurga district after the implementation of the project income level was Rs. 1792 and Rs. Rs.3090.00 (Tables 1 and 2).

Where as in the case of Bangalore Rural and Chickballapur districts, proportion of farmer involved in piggery was found to be 11.64 and 112.02 per cent respectively and were getting income of Rs. 1206.00 and Rs. 800 respectively. After the implementation of the project for piggery, in Bangalore Rural and Chickballapur districts farmers got income of Rs. 2484.36 and Rs. 1648.00 respectively (Tables 3 and 4).

\section{Bee keeping}

In Shimoga and Chitradurga districts, proportion of farmer involved in beekeeping was found to be 9.48 and 9.91 per cent respectively and income was of Rs. 813 and Rs. 500 respectively. For beekeeping, in Shimoga and Chitradurga districts after the implementation of the project farmer income level was Rs.1200 and Rs. 1030.00 respectively (Tables 1 and 2). Where as in the case of Bangalore Rural and Chickballapur districts, proportion of farmer involved in beekeeping was found to be 10.58 and 10.93 per cent respectively and were getting income of Rs. 475.00 and Rs. 465 respectively. After the implementation of the project for beekeeping, in Bangalore Rural and Chickballapur districts farmers got income of Rs. 978.50 and Rs. 957.90 respectively (Tables 3 and 4).

\section{Conclusion}

The success of integrated farming system lies on the farmer who very much involve in almost all farm operations, decision making process and caring of components. Women also participate enthusiastically in many operations. Small farm based IFS should envisage involvement of farm women in the selection of components viz, crops, livestock, poultry, sheep and goat rearing etc. Farmer spending more time for crop production, dairying and horticulture followed by sheep and goat rearing, and help getting more income through employment generation mainly from crop production, dairy, horticulture and kitchen gardening.

Among the cropping sequences under integrated farming systems, yield of crops provided resulted in the maximum (46.32 per cent) closely followed by horticulture (16.77 per

\section{Volume 6 Issue 1, January 2017




\section{International Journal of Science and Research (IJSR) \\ ISSN (Online): 2319-7064 \\ Index Copernicus Value (2015): 78.96 | Impact Factor (2015): 6.391}

cent). Among the animal components dairy produced the higher yield of (12.26 per cent) and followed by piggery (8.07 per cent). In Chickbalapur district a net return obtained from all the components was Rs. 91301.26 per annum, followed by Bangalore Rural district Rs. 80686 followed by Shimoga Rs.76852 and lastly Chitradurga district Rs. 62565 with an increase of 32.3 per cent. Bahera and Mahapatra (1998) also reported increase in returns through IFS. Apart from this also registered 80 per cent of IFS farmers SelfHelp Groups in the cluster villages and established the linkages with all line departments and financial institutions. Provided training on value addition for SC Farm women and farmers.

The necessary inputs like HYV seeds, saplings/grafts, animals (sheep, cow, poultry birds) etc. were distributed to the farmers. The team of specialists will provide the necessary technical guidance. The monitoring and supervision is inbuilt mechanism of the project for effective implementation. The expected outcome is to enhance income to Rs. 32,000 against the baseline income of Rs. 10,000-11,000 and generate self employment opportunities among small and marginal farmers of vulnerable section of society.

\section{References}

[1] Ahsan, R.M., 1986, Proceedings of the workshop on women in Agriculture, Bangladesh Academy for Rural Development, Comilla, 24-25 March.

[2] Allen, V.G., Baker, M.T., Segarra, E and Brown, C.P. 2007, Integrated irrigated crop livestock system in dry climates, American Society of Agronomy, Agron J. 99: 346-360.

[3] Jaim, W.M.H and Rahman, M.D., 1988, Participation of women and children in agricultural activities- A micro level study in an area of Bangladesh, Bangladesh Journal of Agicultural Economics, 11 (1):31-39

[4] Pandurangaiah, K. and Narayana Reddy, M.A., 2007, Role of women in Indian agriculture and its allied activities, All India co-ordinated research project of home science, Souvenir, University of Agricultural Science.

[5] Uddin Nasir Mohammed, 2008, Knowledge of Women in activities to farming system in agrarian community of Bangladesh. 